\title{
CLUSTER ANALYSIS OF EXISTING TECHNOPARKS IN DEVELOPED COUNTRIES
}

\author{
Natalia SHAIDUROVA \\ Kalashnikov Izhevsk State Technical University \\ Vanessa PRAJOVA \\ Slovak University of Technology in Bratislava \\ Vitaliy SMIRNOV \\ Kalashnikov Izhevsk State Technical University \\ Galina LIVENSKAYA \\ Branch of Udmurt State University
}

\begin{abstract}
:
This article provides a cluster analysis of existing technoparks, the sample of which was built according to the completeness of the data presented on the official websites of the Ministry of Industry and Trade of the Russian Federation and the terms of operation. The analysis is carried out in order to determine the best components of the effectiveness of the development of the technopark movement in Russia. According to the analysis of this article, we can talk about a weak relationship between the three sub-indices: the activities of the management company, the activities of residents, the activities of regional authorities. The obtained data can serve as a starting base for further construction of an econometric model of the efficiency factors of technoparks.
\end{abstract}

Key words: technopark, the effectiveness of technoparks, evaluation criteria technoparks, regional economy, innovations, cluster model

\section{INTRODUCTION}

One of the main factors in the development of the Russian economy is the unfocusing of the state budget from the raw materials orientation, moving away from the primitive raw materials economy, and coming to a new, "smart" economy that will be aimed at producing unique knowledge, new things and technologies useful to society, creating the necessary conditions for the effective implementation of the innovation process [13]. New ideas and developments arising in the field of science should pass the stage of transition to the field of production as quickly as possible and turn into a commodity. That is, you need to understand that for a more effective functioning of the innovation sphere, it is necessary that the innovation cycle takes as little time as possible (from the emergence of an idea, knowledge to the commercialization of a product), and it is possible to accelerate the innovation cycle only by aggregating scientists and technologists. In this regard, the experience of various technopark structures as the most successful forms of integration of science and production is of great interest [6].

According to the VI annual review "Technoparks of Russia" of the Association of Clusters and Technoparks of Russia, 179 technoparks are currently operating and being created in 55 regions of the Russian Federation. Over the past years, the positive dynamics of the creation and development of technoparks has been maintained - their geography of their presence, the area of territories and premises is expanding. In the structure of established and operating technoparks, there is a predominance of industrial premises (from $35.9 \%$ in 2016 to $51.1 \%$ in 2019), which is explained by the increase in the number of industrial technoparks [16]. 
Industrial technoparks are one of the key elements of the industrial infrastructure that contributes to the development and development of the production of competitive products, the expansion of cooperation between small technology companies and large businesses, as well as the introduction of advanced production technologies.

When creating and operating technoparks, three entities are interconnected in the direct chain: the management company of the technopark, the residents of the technopark and the regional authorities. The advantages of an industrial technopark for these subjects can be represented in the following aspects [24]:

- for the site owner: more efficient management of the site and the existing infrastructure; the possibility of additional income from providing services to residents of the technopark; the possibility of hosting partners (suppliers or consumers of goods or services);

- for residents: cost reduction, release of funds for the implementation of high-tech projects, re-profiling; the possibility of obtaining a range of services in the "single window" format; access to the necessary industrial equipment;

- for the region: new growth points; increase of jobs number, increase of tax revenue; increase of the investment attractiveness of the region.

Despite the seemingly strong sides of technoparks, there are a number of weaknesses, one of which is the uneven development of industry in the regions of the Russian Federation, and as a result, the uneven distribution of technoparks (the largest number of them falls on the Central (50\%) and Volga (20\%) federal districts), the second, the uneven support of management companies and residents from state authorities, the next weak side can be the difficulty of attracting private investors at the initial stage of projects of residents of technoparks, there is also a lack of personnel in the regions and an insufficient level of competence in the development and promotion of innovative products [3].

For these reasons, it is extremely important to identify the factors of the effectiveness of technoparks through direct or inverse relationships between seemingly interrelated subjects of the technopark movement.

\section{MATERIAL AND METHODS}

In order to identify the factors of the effectiveness of the functioning of technoparks, it is necessary to determine an effective indicator that comprehensively assesses all aspects of the technopark's activities [15]. There is still no consensus on this indicator in the scientific and business community.

To date, a significant number of scientific papers devoted to the importance of various criteria for evaluating the effectiveness of technoparks have been published.

Thus, most experts are of the same opinion that the effectiveness of the technopark is measured by the effectiveness of residents. At the same time, it is necessary to understand that the technopark is an independent economic entity of the economy and its functioning should be eval- uated regardless to the effectiveness of its residents' activities [10]. But it should be remembered that the main activity of the technopark management company is to manage the creation, development and operation of an industrial technopark, as well as to provide residents of an industrial technopark with the services they need to carry out manufacturing of industrial products, scientific and technical activities and (or) innovative activities in order to master the production of industrial products and commercialize the scientific and technical results obtained [9]. Therefore, the effectiveness of the residents of the technopark serves as a proxy for evaluating the effectiveness of the technopark (the more effective the residents, the more effective the management in the technopark). On the other hand, the effectiveness of a technopark resident depends only on the effectiveness of the resident's management. And with the competent management of a technopark resident, the choice of the technopark itself will depend on the effectiveness of the management of the technopark's management company [14]. Thus, the task of the effectiveness of the technopark's activities is reduced to finding an indicator that takes into account the effectiveness of the assistance of the technopark's management company in the effectiveness of the activities of their residents.

Kostyunina, G., Baranov, V. (2012) claim that the measure of the effectiveness of the technopark is the number of jobs created, and the effectiveness of the technopark is determined by the economic development of the region in which it is located. In our opinion, it should be remembered that a technopark is a commercial organization that derives income from providing services to residents, and a resident of a technopark is an enterprise or an individual entrepreneur whose purpose is to make a profit. For this reason, the creation of jobs for the technopark and the resident of the technopark is not a productive indicator of their activities, to a greater extent it can be called a social indicator of their functioning [7].

P. Sobkowic (2013) suggests evaluating the success of the technopark by the number of established companies launching new products or services, thereby speeding up the process of access and transfer of technologies, knowledge, experience and skills among the residents of the technopark [12]. The same opinion is shared by the authors Albahari and all (2012), seeing the effectiveness of the technopark in the number of resident companies as generators of innovative products of the technopark. In our opinion, this evaluation criterion cannot be considered a productive indicator, because it does not assess either the number of innovative products created or their commercialization on the market [1].

Not all innovations developed by residents can be brought to the market, and the creation of innovations in itself, as well as the creation of innovative companies, cannot be an end in itself. Since innovation is a new or significantly improved product (goods, service) or process introduced for use, a new sales method or a new organizational method in business practice, workplace organization or in 
external relations [2, 4, 5], and innovative activity - scientific, technological, organizational, financial and commercial activities aimed at implementing innovative projects, as well as creating innovative infrastructure and ensuring its activities $[5,11]$ must be in demand by the market, i.e. commercialized-involved in the economic turnover of scientific and (or) scientific and technical results [5]. N. N. Lytaeva, V. S. Lipatnikov (2018) approach the effectiveness of technoparks through the total value of sales of products of residents of the technopark, mainly of an innovative nature. Taking into account the above authors' research, we can try to offer a cluster analysis of technoparks by three top-level sub-indexes (classification without training) [8].

The study considered three top-level subindexes:

s1 - the activity of the management company;

s2 - activities of residents;

s3 - activities of regional authorities.

Each upper-level subindex includes middle-level subindexes, which in turn include lower-level subindexes in accordance with Table 1.

\section{The methodology of the statistical study included 3 main stages}

Data transformation

In order to exclude the influence of the dimension of the values on the analysis result, data standardization was performed, as a result of which each lower-level subindex was reduced to an average value of 0 and a standard deviation of 1 .

The middle-level subindexes were calculated as the arithmetic mean of the lower-level subindexes and were further standardized [18]. The top-level subindexes were calculated as the arithmetic mean of the middle-level subin- dexes and were also standardized. As a result, all subindexes have a single dimensionless scale.

\section{Primary data analysis}

Histograms of the distribution of subindexes were constructed and their main characteristics were determined (minimum and maximum values, median, coefficient of asymmetry).

Cluster analysis of technoparks by three top-level sub-indexes (classification without training)

To determine the number of clusters, the "elbow" method was used. The hierarchical clustering procedure was used with the following parameters: measuring the distance between objects - the Euclidean distance, measuring the distance between clusters - the unweighted average distance between all pairs of elements (in order to reduce the impact of outliers on the result of cluster analysis) [20]. Clustering by the K-means method was used to divide technoparks into clusters.

\section{Source data}

The sample was formed from 64 operating technoparks that provided a complete set of data to the state information system of industry of the Ministry of Industry and Trade of Russia (https://gisp.gov.ru/gisplk/), the period of operation of which is more than 3 years (in order to identify the dynamics of revenues, the creation of innovative products, the payment of taxes).

The study involved 20 technoparks ( 31\%) from 6 federal districts (Central, North-Western, Volga, Ural, North Caucasus and Far Eastern) and 13 regions of the Russian Federation. Table 2 shows the data of a sample of technoparks participating in the study [17].

Table 1

Subindexes of the upper, middle and lower levels

\begin{tabular}{|c|c|c|c|}
\hline \multirow{11}{*}{ s1 } & \multirow{5}{*}{ s11 } & s111 & Infrastructure. Availability of technological infrastructure. \\
\hline & & s112 & Infrastructure. Availability of social infrastructure. \\
\hline & & s113 & Infrastructure. Availability of engineering infrastructure. \\
\hline & & s114 & Infrastructure. Types of technological equipment provided for rent by a resident \\
\hline & & s121 & Transport. Distance to the city center, $\mathrm{km}$ \\
\hline & \multirow[t]{2}{*}{ s12 } & s122 & Transport. Distance to the railway station, $\mathrm{km}$ \\
\hline & & s123 & Transport. Distance to the airport, $\mathrm{km}$ \\
\hline & \multirow[t]{2}{*}{ s13 } & s13 & Number of specializations \\
\hline & & s141 & Management. Provision of technopark residents with services, points. \\
\hline & \multirow[t]{2}{*}{ s14 } & s142 & $\begin{array}{l}\text { Management. The volume of attracted direct investments per } 1 \text { sq. m. of the total area of the technopark prem- } \\
\text { ises, million rubles/sq. m. }\end{array}$ \\
\hline & & s143 & Management. The level of occupancy of the area. \\
\hline \multirow{6}{*}{ s2 } & s21 & s21 & Innovative activity. The amount of intellectual property objects registered by residents, units. \\
\hline & \multirow{5}{*}{ s22 } & s221 & Economic activity. The average annual growth rate of residents ' revenue, $\%$ \\
\hline & & s222 & Economic activity. The average level of labor productivity, thousand rubles. \\
\hline & & s223 & Economic activity. The average level of taxes of park residents per 1 employee, thousand rubles/person. \\
\hline & & s224 & $\begin{array}{l}\text { Economic activity. The volume of investments of residents in fixed assets per } 1 \text { employee of a resident company, } \\
\text { million rubles/person. }\end{array}$ \\
\hline & & s225 & $\begin{array}{l}\text { Economic activity. The volume of industrial production of residents of the industrial technopark for } 1 \text { rub. invest- } \\
\text { ments of residents of the park, million rubles/ million rubles. }\end{array}$ \\
\hline \multirow{2}{*}{ s3 } & s31 & s31 & Region. Points for the average rating of investment attractiveness for 2019,2020 , points. \\
\hline & s32 & s32 & Region. Support programs, points. \\
\hline
\end{tabular}


Table 2

Data from technoparks

$\begin{array}{ccccc}\text { No. Federal } & \text { Region } & \text { Technopark } & \text { Year } & \text { Site type } \\ \text { District } & \text { Form creation } & \text { ownership }\end{array}$

\begin{tabular}{|c|c|c|c|c|c|c|}
\hline 1 & Central & Moscow & Technopolis "Moscow" & 2012 & Brownfield & Private \\
\hline 2 & North-West & Pskov region & Technopark " Electropolis" & 2017 & Brownfield & Private \\
\hline 3 & Privolzhsky & $\begin{array}{l}\text { Republic } \\
\text { of Bashkortostan }\end{array}$ & Technopark "HTC UAI-Rosoil " & 2009 & Brownfield & Private \\
\hline 4 & Central & Moscow & Technopark" Slava" & 2008 & Brownfield & Mixed \\
\hline 5 & North-West & Saint-Petersburg & Technopark of St. Petersburg & no data available & Brownfield & State-owned \\
\hline 6 & Privolzhsky & Republic of Mordovia & Technopark of the Republic of Mordovia & 2012 & Brownfield & State-owned \\
\hline 7 & Central & Moscow oblast & Technopark "Skhodnya-Grand" & no data available & Brownfield & Private \\
\hline 8 & Central & Moscow & Technopark" Strogino " & 2007 & Brownfield & State-owned \\
\hline 9 & Central & Voronezh Region & Technopark" Commonwealth " & 2007 & Brownfield & Private \\
\hline 10 & Uralsky & Sverdlovsk region & $\begin{array}{l}\text { Technopark" Novouralsky" } \\
\text { Technopark "Scientific and Technological }\end{array}$ & 2012 & Brownfield & Private \\
\hline 11 & Siberian & Novosibirsk region & $\begin{array}{l}\text { Park of Novosibirsk Akademgorodok" } \\
\text { (Akadempark) }\end{array}$ & 2010 & Brownfield & Mixed \\
\hline 12 & Central & Moscow & Technopark "Nagatino" & 2015 & Brownfield & State-owned \\
\hline 13 & Central & Lipetsk region & $\begin{array}{l}\text { Municipal budgetary institution " Tech- } \\
\text { nopark-Lipetsk }\end{array}$ & 2012 & Brownfield & Municipal \\
\hline 14 & Central & Moscow & Technopark "Mosgormash" & 2013 & Brownfield & State-owned \\
\hline 15 & $\begin{array}{l}\text { North } \\
\text { Caucasian }\end{array}$ & Stavropol Territory & Technopark " Monocrystal" & 2016 & Brownfield & Private \\
\hline 16 & Central & Voronezh Region & Technopark " Cosmos-oil-gas" & 2006 & Brownfield & Private \\
\hline 17 & Volga Far & Republic of Tatarstan & Technopark " KNIAT" & 2003 & Brownfield & Mixed \\
\hline 18 & Eastern & $\begin{array}{l}\text { Republic of Sakha } \\
\text { (Yakutia) }\end{array}$ & $\begin{array}{l}\text { State Autonomous Institution of the Repub- } \\
\text { lic of Sakha (Yakutia) Technopark "Yakutia" }\end{array}$ & 2012 & Greenfield & State-owned \\
\hline 19 & Privolzhsky & Republic of Tatarstan & Technopark "Aviator" & 2017 & Brownfield & Private \\
\hline 20 & Privolzhsky & Samara region & Technopark "Zhigulevskaya valley" & 2014 & Brownfield & State-owned \\
\hline
\end{tabular}

\section{RESULTS OF THE STUDY}

The values of the top-level subindexes are shown in Table 3.

Table 3 Values of top-level subindexes

\begin{tabular}{cccc}
\hline No. & s1 & s2 & s3 \\
\hline 1 & -0.971 & -0.537 & 2.1357 \\
2 & 0.8367 & 0.5433 & -1.724 \\
3 & 0.0174 & -0.933 & -0.485 \\
4 & -0.19 & 3.5058 & 0.9275 \\
5 & 2.3975 & 0.235 & 0.0137 \\
6 & 0.6052 & 1.0303 & -1.344 \\
7 & 0.5287 & 0.5791 & 0.2334 \\
8 & -1.324 & 0.3462 & 1.3302 \\
9 & -1.487 & -0.616 & -0.485 \\
10 & -1.108 & -0.002 & -0.497 \\
11 & -0.267 & -0.178 & -0.228 \\
12 & -0.165 & -0.289 & 1.1228 \\
13 & -0.476 & -0.149 & -0.119 \\
14 & 0.0212 & -0.114 & 1.135 \\
15 & 0.315 & -0.728 & -1.152 \\
16 & -0.061 & -0.433 & -0.68 \\
17 & -1.188 & -1.059 & 0.6361 \\
18 & 0.2335 & -0.736 & -1.13 \\
19 & 0.3548 & -0.81 & 0.4043 \\
20 & 1.9275 & 0.3429 & -0.095 \\
\hline & & &
\end{tabular}

Figure 1 shows the distribution of technoparks in the coordinate system s1-s2-s3.

The primary analysis of Table 3 and Figure 1 shows that Technopark No. 4 stands out significantly in comparison with other technoparks in terms of the $s 2$ subindex.

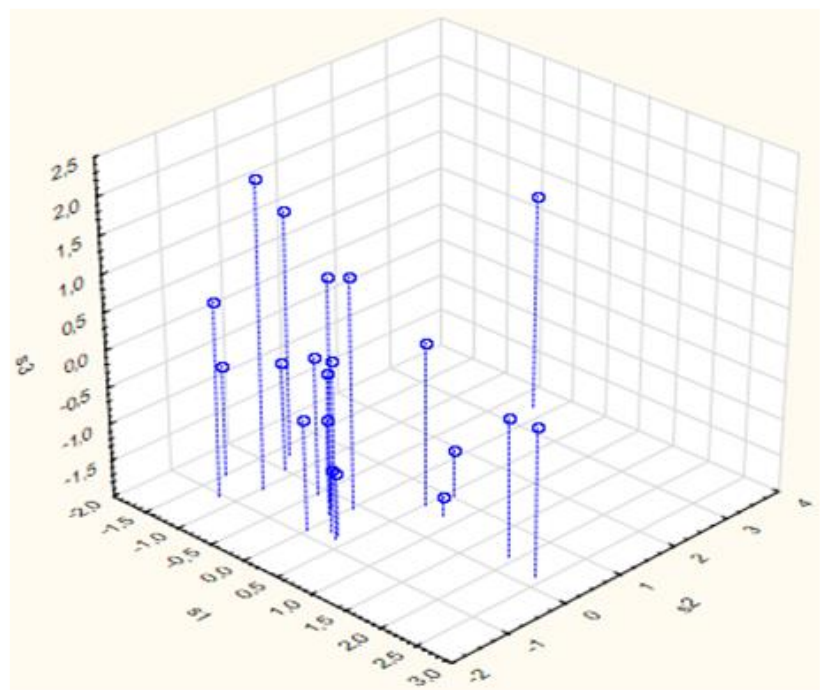

Fig. 1 Distribution of technoparks in the coordinate system s1-s2-s3

Figure 2 shows the histograms of the distribution of the top-level subindexes. 

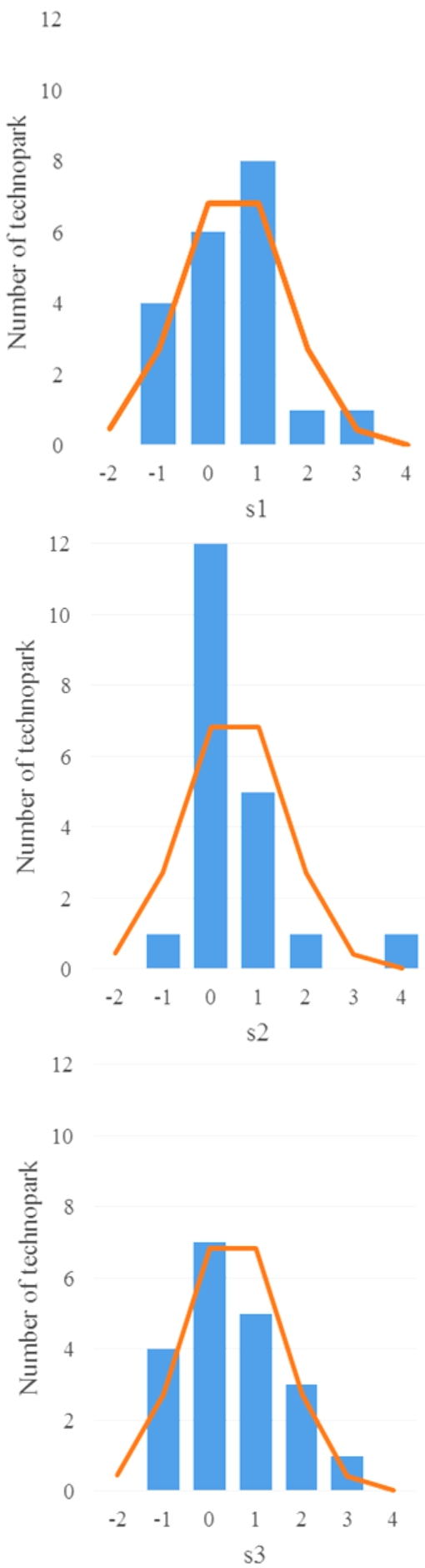

Fig. 2 Histograms of the distribution of top-level subindexes

It is necessary to pay attention to the presence of a positive asymmetry (skew to the left) of the distributions of all three subindexes [19]. This is due to the fact that a relatively small number of technoparks have values of subindexes s1, s2, s3, significantly exceeding their average values. According to Figure 2, it can be seen that from 60 to $80 \%$ of technoparks have subindex values close to the average values (from -1 to 1 ).

Next, let's move on to the results of cluster analysis. The first task was to determine the optimal number of clusters [23].
As a result of hierarchical clustering, the dependence of the cluster union distance on the number of clusters was obtained (Figure 3).

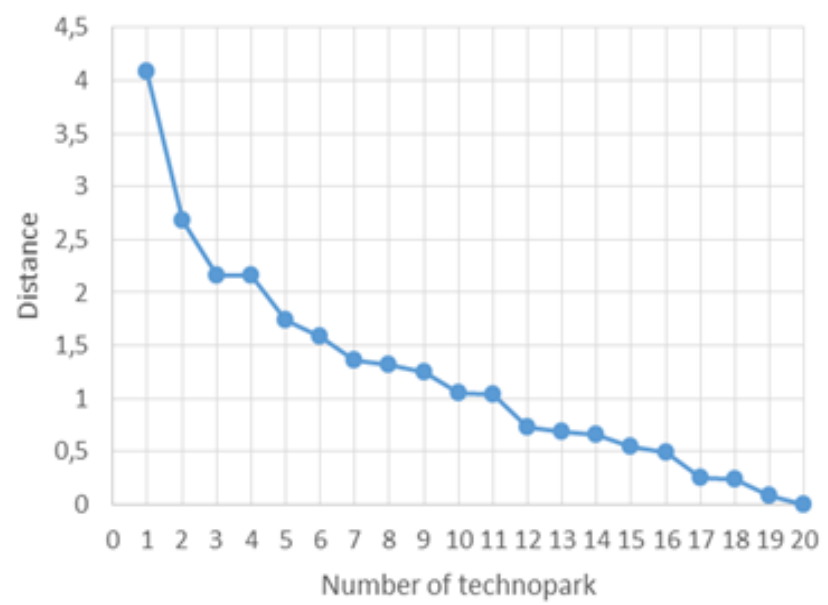

Fig. 3 Dependence of the cluster joining distance on the number of clusters

In Figure 3, the fracture point of the graph is clearly visible, corresponding to the number of clusters $k=3$. As a result, 3 clusters were taken as a basis.

The division of technoparks into clusters was carried out using the K-means method with an indication of the number of clusters $k=3$. The result of the partition is shown in Figures 4, 5.

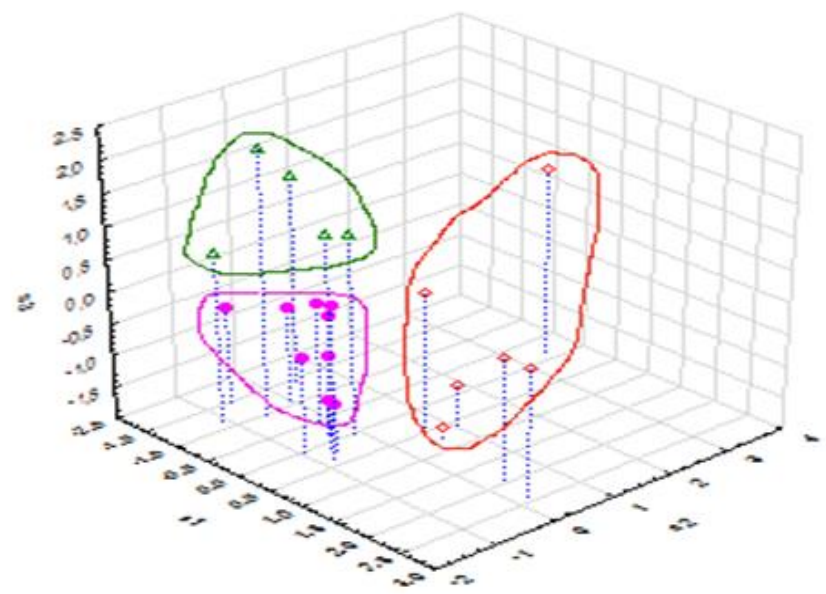

Fig. 4 The result of clustering by the K-means method

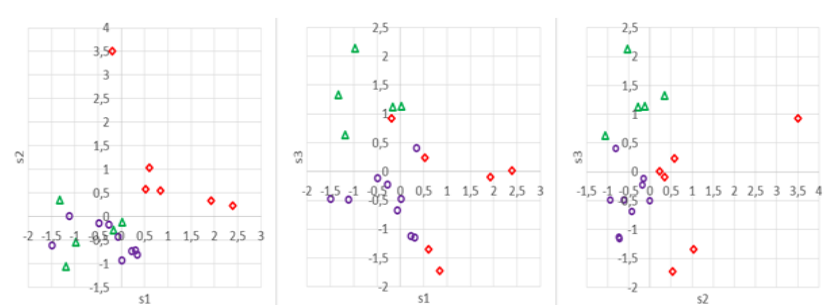

Fig. 5 The result of clustering by the $K$-means method

Table 4 and Figure 6 show the average values of each subindex for each of the three clusters. 
Table 4 Average values of sub-indexes for each cluster

\begin{tabular}{|c|c|c|c|}
\hline & Cluster 1 & Cluster 2 & Cluster 3 \\
\hline no. of technoparks & $\begin{array}{l}2,4,5,6 \\
\quad 7,20\end{array}$ & $\begin{array}{c}1,8,12,14 \\
17\end{array}$ & $\begin{array}{c}3,9,10,11 \\
13,15,16 \\
18,19\end{array}$ \\
\hline $\begin{array}{l}\text { s1 - Activities of the man- } \\
\text { agement company }\end{array}$ & 1,017626 & $-0,725435$ & $-0,275398$ \\
\hline s2 - Activities of residents & 1,039409 & $-0,330490$ & $-0,509334$ \\
\hline $\begin{array}{l}\text { s3 - Activities of regional } \\
\text { authorities }\end{array}$ & $-0,331357$ & 1,271961 & $-0,485741$ \\
\hline
\end{tabular}

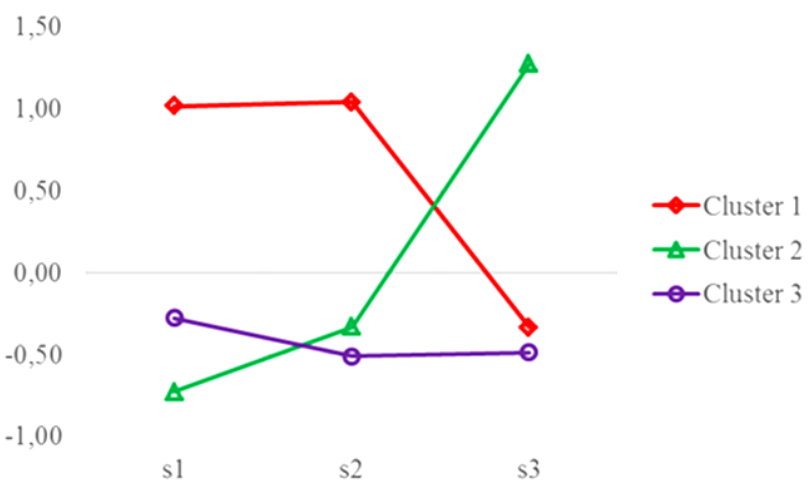

Fig. 6 Average values of subindexes for each cluster

Table 5

Clustering results

\begin{tabular}{llll}
\hline Cluster & Technopark & Region & Characteristics of the cluster
\end{tabular}

Technopark "Electropolis"

Technopark "Slava"

Technopark of St. Petersburg

Cluster 1

Technopark of the Republic of Mordovia

Technopark "Skhodnya-Grand "

Technopark "Zhigulevskaya valley"

Technopolis "Moscow"

Technopark "Strogino"

Cluster 2 Technopark "Nagatino"

Technopark "Mosgormash"

Technopark "KNIAT"

Technopark "KHTC UAI-Rosoil"

Technopark "Sodruzhestvo"

Technopark "Novouralsky"

Technopark "Scientific and Technological Park of Novosibirsk Akademgorodok (Akadempark)
Pskov region

Moscow

Saint-Petersburg

Republic of Mordovia

Moscow oblast

Samara region

Moscow

Moscow

Moscow

Moscow

Republic of Tatarstan

Republic of Bashkortostan

Voronezh Region

Sverdlovsk region

Novosibirsk region

Lipetsk region

Stavropol Territory

Voronezh Region

Republic of Sakha (Yakutia)

Republic of Tatarstan
With a slightly lower than average level of activity

of regional authorities and significantly higher than the average level $f$ activity of residents, the level

of activity of the technopark's management company is significantly higher than average.

At a level significantly higher than the average level of activity of regional authorities and slightly lower than the average level of activity

of residents, the level

of activity

of the management company is significantly lower than the average.

\section{With the level of activity}

regional authorities below the average and even more below the average of residents, the level of activity

of the management company is slightly below the average.

State Autonomous Institution of the Republic of Sakha (Yakutia) Technopark "Yakutia" 


\section{DISCUSSION}

Nevertheless, we adhere to the opinion of the authors who consider the effectiveness of technoparks to be a complex effective indicator that takes into account the effectiveness of the management company itself and the effectiveness of the residents of the technopark.

Based on the results of the analysis, the following two conclusions can be drawn:

1. With high performance indicators of management companies and residents of the technopark, the level of activity of regional authorities is slightly below average. Therefore, with slightly lower standard operating conditions in the region, the total activity of the technopark is high [22]. The regional authorities, seeing the economic, financial and social indicators of the technopark's activity (including the management company and residents), do not create additional preferences for the subjects of the technopark movement.

2. Seeing the activity of the management companies of technoparks as significantly below the average and slightly below the average activity of residents, the regional authorities create favorable conditions for improving these indicators. In another case, when the activity of regional authorities is significantly higher than the average, the management companies of technoparks have the lowest level below the average and the activity of residents is slightly below the average [21]. This may indicate the low efficiency of the proposed preferences of the regional authorities.

3. At the lowest below average level of activity of regional authorities, the activity of management companies of technoparks is slightly below average and the activity of residents is below average. It can be assumed that the regional authorities, seeing the activities of the management companies of technoparks slightly below the average and the activities of residents below the average, do not offer additional preferences to the subjects of the technopark movement. At least, such conclusions can be reached based on the data provided by management companies to the Ministry of Industry and Trade of the Russian Federation. You can see the correlation between the presented indices in Table 6 .

Table 6 Correlation analysis of sub-indices

\begin{tabular}{cccc}
\hline & S1 & S2 & S3 \\
\hline S1 & 1,000000 & 0,193031 & $-0,330023$ \\
S2 & 0,193031 & 1,000000 & 0,087914 \\
S3 & $-0,330023$ & 0,087914 & 1,000000 \\
\hline
\end{tabular}

The correlation matrix shows that there is no strong correlation between the sub-indices.

\section{CONCLUSION}

Today, industrial technoparks are an important tool for the development of high-tech sectors of Russian industry with high growth potential.
The conducted cluster analysis of the technopark movement indicates the determination of a complex effective indicator of the activity of the technopark movement as a whole. Thus, the sub-indices presented above have a weak correlation between them.

Our research was limited to the data provided by the management companies of technoparks and the results were obtained for a sample of technoparks that provided the full amount of information, therefore, registration errors are possible in the presented analysis, excluding representativeness errors.

Another area of future research is the construction of an econometric model of the efficiency factors of technoparks.

\section{ACKNOWLEDGMENT}

This publication has been written thanks to support of the research project project KEGA 013TUKE-4/2019 "Modern educational tools and methods for shaping creativity and increasing the practical skills and habits of graduates of technical departments of universities".

\section{REFERENCES}

[1] A. Albahari, A. Barge-Gil, S. Perez-Canto, S. Modrego-Rico, A. The Influence of Science and Technology Park Characteristics on Firms' Innovation Results. MRPA Paper 49227, University Library of Munich, Germany. 2013

[2] V. Bogers, J. West. Strategic Utilization of Open and User Innovation//Creativity and Innovation Management, In: Managing Distributed Innovation, 21 (1), 2012. pp. 61-75.

[3] N. Bozo, A. Diner. The ecosystem of Russian technoparks: the issues of creation and development. Bulletin of the Tomsk State University. Economy, 1(33), 2016, pp. 105115.

[4] A. R. Datta, L. Jessup. Factors Affecting the Governance of Innovation Commercialization: A Theoretical Model//Journal of Business and Management, 18 (1), 2012, pp. 31-59.

[5] Federal Law of the Russian Federation Industrial Policy in the Russian Federation (with amendments as of August 2, 2019). Access mode: http://docs.cntd.ru/document/420242984

[6] R. Gost: 56425-2015 National standard of the Russian Federation technoparks Requirements. Pre-stop mode: http://docs.cntd.ru/document/1200121795

[7] G. Kostyunina, V. Baranov. Technoparks in foreign and Russian practice. Bulletin of MGIMO, 3, 2012, pp. 91-99.

[8] N. Lytaeva, V. Lipatnikov. Success factors of Russian technoparks: an econometric model Innovative economy, 4, 2018, pp. 85-95.

[9] Materials on the results of the online seminar of the Ministry of Industry and Trade of Russia and AKIT: "Industrial technoparks: mechanisms of state support and federal requirements" (25.02.2021) https://akitrf.ru/technoparks/analiticheskie-materialy/

[10] Zh. Mingaleva, N. Shaidurova. Interaction of state and local authorities in the creation and development of tehnology parks. Ars Administrandi, 9(2), 2017, pp. 176-194.

[11] N. Rosenbush, J. Brinckman, A. Bausch. Is innovation always beneficial? A meta-analysis of the relationship between innovation and performance in SMEs//Journal of Business Venturing, 26 (4), 2011, pp. 441-457. 
[12] P. Sobkowic. The role of science and technology parks in communication processes between research institutions and industry//Marketing Instytucji Naukowych $i$ Badawczych, 4 (10), 2013, pp. 2-18.

[13] R. Schroll, J. Janot, B. Král, I. Králiček. Managerial accounting in market economy companies. Praha, VŠE 2003, pp. 67-88.

[14] R. Šlosár, A. Šlosárová. Double entry accounting for entrepreneurs. Bartislava, Ekonómia 2005, pp. 52-69.

[15] J. Hilmar, J. Vollmuth. Controlling - new management tool. Praha, Profess Consulting 2009, pp. 124-143.

[16] R. Hardt. Kostenmanagement: Instrumente und Methoden. München, Oldenbourg-Verlag 2007, pp. 40-86.

[17] The comprehensive program "Creation of technoparks in the field of high technologies in the Russian Federation". Access mode: http://docs.cntd.ru/document/901971445

[18] K. Kaszasová, I. Paule. Auditing. Bratislava, Súvaha 2005, pp. 28-54.

[19] J. Kemmetmueller, S. Bogenberger. Handbuch der Kosterechnung, WUV Wien 2010, pp.125-137.

[20] A. Kumar, P.K. Jain, P.M. Pathak. Reverse Engineering in Product Manufacturing: An Overview. DAAAM International Scientific Book, 2013, pp. 665-679.

\section{Natalia Shaidurova}

ORCID ID: 0000-0003-4911-0772

Kalashnikov Izhevsk State Technical University

Department of Economics and Organization of Production

1 Shuvalov str., Votkinsk, 427433, Russia

\section{Vanessa Prajova}

ORCID ID: 0000-0002-1260-4675

Slovak University of Technology in Bratislava, Slovak Republic e-mail: vanessa.prajova @stuba.sk

\section{Vitaliy Smirnov}

ORCID ID: 0000-0002-4536-0160

Kalashnikov Izhevsk State Technical University

Department of Mechanical Engineering

and Instrument Engineering Technology

1 Shuvalov str., Votkinsk, 427433, Russia

\section{Galina Livenskaya}

ORCID ID: 0000-0003-0487-7179

Branch of Udmurt State University in Votkinsk

Department of Economics, Management and Law

1 Raskova str., Votkinsk, 427433, Russia
[21] M. Paulic, T. Irgolic, J. Balic, F. Cus, A. Cupar, T. Brajlih, I. Drstvensek. Reverse Engineering of Parts with Optical Scanning and Additive Manufacturing, Procedia Engineering, Volume 69, 2014, pp. 795-803

[22] I. Matyushchenko, E. Zvereva, T. Lavina, Development of Algorithmic Thinking by Means of Lego Mindstorms Ev3 on Robotics. In: Ural Symposium on Biomedical Engineering, Radioelectronics and Information Technology (USBEREIT). 2020, pp. 444-447

[23] O. Cordón, F. Gomide, F. Herrera, F. Hoffmann, L. Magdalena. Ten years of genetic fuzy systems: current framework and new trends. Fuzzy sets and systems, 2004, pp. 141, 531

[24] T. Zavyalova, A. Andreeva. Mechanisms for the development of technoparks as a tool for the transfer of innovative technologies. Economic sciences, 2(183), 2020, pp. 4450 . 